Copyright (c) 2015 SBPjor / Associação Brasileira de Pesquisadores em Jornalismo

\section{PHOTOJOURNALISM IN THE BELÉM PRESS: I9O0-I950}

NETÍLIA SILVA DOS ANJOS SEIXAS

Universidade Federal do Pará, Brazil

THAÍS CHRISTINA COELHO SIQUEIRA

Universidade Federal do Pará, Brazil

\begin{abstract}
This study looks at the course of photojournalism in the first half of the 20th century in the Belém press, in the State of Pará. This is exploratory research based on the iconographic and iconological analysis of images as understood by Panofsky and Kossoy. Bibliographical and documentary research together with an empirical analysis of data was conducted on three important newspapers in Pará: A Província do Pará, Folha do Norte and Estado do Pará, all available in the archives of the Arthur Vianna Public Library in Belém. Analyzing the data made it possible to provide a picture of the course of photojournalism in Pará for the major newspapers in circulation during the established time period, showing that even at the beginning of the century periodicals already recognized the power of images; something evident in publication. The data also showed that problems in the city, wars, politics, police and sports were the main issues for photojournalism in Pará throughout the decades studied in this paper.
\end{abstract}

Keywords: Journalism. Photojournalism. The Pará Press. 20th Century.

\title{
FOTOJORNALISMO NA IMPRENSA DE BELÉM: 1900 - 1950
}

RESUMO - Esta pesquisa visou a observar o percurso do fotojornalismo na imprensa de Belém, Pará, na primeira metade do século XX. Trata-se de estudo exploratório, baseado em análise iconográfica e iconológica das imagens, segundo Panofsky e Kossoy. Foram realizadas pesquisas bibliográfica, documental e análise de dados empíricos de três importantes jornais do Pará: A Província do Pará, Folha do Norte e Estado do Pará, disponíveis no acervo da Biblioteca Pública Arthur Vianna, em Belém. Com a análise dos dados, foi possível traçar um panorama do percurso do fotojornalismo paraense nos principais jornais em circulação no período definido, observando que, mesmo no início do século, os periódicos já reconheciam a força das imagens e isso era perceptível na sua enunciação. Os dados mostraram também que os problemas da cidade, guerras, política, polícia e esportes eram as principais temáticas do fotojornalismo paraense nas décadas estudadas.

Palavras-chave: Jornalismo. Fotojornalismo. Imprensa no Pará. Século XX. 


\section{FOTOPERIODISMO EN LA PRENSA DE BELÉM: 1900-1950}

RESUMEN - Esta investigación tuvo como objetivo observar el curso de fotoperiodismo en la prensa de Belém, Pará, en la primera mitad del siglo XX. Se trata de un estudio exploratorio, basado en el análisis iconográfico y iconológico de las imágenes, según Panofsky y Kossoy. Se llevó a cabo la investigación bibliográfica, documental y el análisis de los datos empíricos de los tres principales periódicos del Pará: A Provincia do Pará, Folha do Norte y Estado do Pará, disponibles en la colección de la Biblioteca Pública Arthur Vianna, en Belém. Con el análisis de los datos, fue posible hacer un panorama del fotoperiodismo del Pará en los principales periódicos de circulación en el período definido, teniendo en cuenta que incluso en el comienzo del siglo, los periódicos ya reconocían el poder de las imágenes y esto fue evidente en su expresión. Los datos también mostraron que los problemas de la ciudad, las guerras, la política, la policía y los deportes eran los principales temas del fotoperiodismo del Pará en las décadas estudiadas.

Palabras clave: Periodismo. Fotoperiodismo. Prensa en Pará. Siglo XX.

\section{INTRODUCTION}

This article is an exploratory research' with the objective of providing an overview of the course of photojournalism in print media during the first half of the twentieth century in Para. It is an attempt to try and identify when the first photographs considered as photojournalism emerged and how they were inserted in journalism in this period. In order to do this, we used some parts of discussions from Panofsky (1976) and Kossoy (2001) on iconography and iconology as they apply to analyzing photographs.

To arrive at our results a bibliographical and documentary research was conducted along with an iconographic and iconological analysis (PANOFSKY, 1976; KOSSOY, 2001) of empirical data from three newspapers: A Província do Pará (1876 - 2002), Folha do Norte (1896 - 1974) and Estado do Pará (1911 - 1980). These newspapers were chosen according to their criteria of importance, periodicity and availability in the Microfilm and Periodical archives of the Arthur Vianna Public Library (BPAV) in Belém-PA. The photographs were analyzed according to image description and were subsequently matched with the historical context they were produced in. The number of editions observed is in Table 1 : 
Table 1 - Number of editions observed per newspaper from 1900 to 1950.

\begin{tabular}{|c|c|c|c|c|c|c|c|c|c|c|c|c|}
\hline \multicolumn{5}{|c|}{ A Província do Pará } & \multicolumn{4}{|c|}{ Folha do Norte } & \multicolumn{4}{|c|}{ Estado do Pará } \\
\hline Month & \multirow{2}{*}{ Jan } & \multirow{2}{*}{ Apr } & \multirow{2}{*}{ Jul } & \multirow{2}{*}{ Oct } & \multirow{2}{*}{ Jan } & \multirow{2}{*}{ Apr } & \multirow{2}{*}{ Jul } & \multirow{2}{*}{ Oct } & \multirow{2}{*}{ Jan } & \multirow{2}{*}{ Apr } & \multirow{2}{*}{ Jul } & \multirow{2}{*}{ Oct } \\
\hline Year & & & & & & & & & & & & \\
\hline 1900 & 30 & 26 & 30 & 31 & 31 & 30 & 31 & 31 & \multicolumn{4}{|c|}{ Not published yet } \\
\hline 1910 & \multicolumn{2}{|c|}{ No records } & 31 & $\begin{array}{l}\text { No } \\
\text { records }\end{array}$ & 31 & 30 & 31 & 31 & \multicolumn{4}{|c|}{ Not published yet } \\
\hline 1912 & 31 & 30 & 31 & $\begin{array}{l}\text { Was not in } \\
\text { circulation }\end{array}$ & 31 & 30 & 24 & 31 & 31 & 30 & 31 & 31 \\
\hline 1920 & $\begin{array}{l}\text { Was } \\
\text { circ }\end{array}$ & $\begin{array}{l}\text { t in } \\
\text { tion }\end{array}$ & 25 & 31 & 31 & 30 & 31 & 31 & 31 & 30 & 31 & $\begin{array}{l}\text { No } \\
\text { records }\end{array}$ \\
\hline 1930 & \multicolumn{4}{|c|}{ Was not in circulation } & 31 & 30 & 25 & $\begin{array}{l}\text { No } \\
\text { records }\end{array}$ & \multicolumn{4}{|c|}{ On microfilm } \\
\hline 1940 & \multicolumn{4}{|c|}{ Was not in circulation } & 31 & 30 & 30 & 31 & \multicolumn{4}{|c|}{ On microfilm } \\
\hline 1950 & 25 & 25 & 25 & 23 & 31 & 30 & 31 & 31 & \multicolumn{4}{|c|}{ On microfilm } \\
\hline $\begin{array}{c}\text { Total } \\
\text { per } \\
\text { paper }\end{array}$ & \multicolumn{4}{|c|}{394} & \multicolumn{4}{|c|}{816} & \multicolumn{4}{|c|}{215} \\
\hline $\begin{array}{l}\text { Total } \\
\text { editi- } \\
\text { ons }\end{array}$ & \multicolumn{12}{|c|}{1.425} \\
\hline
\end{tabular}

Source: Research data from the Arthur Vianna Public Library archives, Belém-Pará.

In a previous study (SEIXAS, $2011 \mathrm{~d}$, p. 12), we observed that in 1912, more specifically the month of September, the Estado do Pará newspaper published photographs that could be considered journalistic, something the other two newspapers Folha do Norte and $A$ Província do Pará did not have. This study also did not find any record of journalistic photography in the pages of the newspapers selected before 1912 in the defined periods. Images ${ }^{2}$ had been used to illustrate material before but they were always illustrations of photographs. Seeing as how the year 1912 was not included in the clipping for this study, we saw that it was important to include it in our analysis.

In line with Sousa (2002, p. 7), we believe that photojournalism is any photograph considered "newsworthy" meaning it has "newsvalue", which is something the communication company determines and attaches to the side of a text, helping to give additional information about certain facts. In other words, in order for an image to be classified as journalistic photography, more than anything it needs to inform. "Journalistic photography shows, reveals, exposes, reports and is opinionated. It gives information and lends to the credibility of textual information" (SOUSA, 2002, p. 5).

In this way, we lead off with the following questions in relation to the Para press: what has been the history of 
photojournalism in periodicals since its inception? How has photography gained ground in journalistic production on a local level? We seek to understand these questions by observing the collected data. Before that, we will present some data on the actual press in Brazil and in Para.

\section{$19^{\text {TH }}$ CENTURY: THE PRESS IN BRAZIL AND PARÁ}

Fourteen years after the press had been created in Brazil in 1808, O Paraense (1822-1823) emerged on May 22, 1822, founded by Filippe Alberto Patroni Martins Maciel Parente and Daniel Garção de Mello. This marked not only the beginning of the press in the Province of Para but in the entire Amazon region which made it "one of the first Brazilian Provinces to meet the press" (COELHO, 2008, p. 26).

In the second half of the nineteenth century, other newspapers, journals and various periodicals were published (BIBLIOTECA PÚBLICA DO PARÁ, 1985; SEIXAS, 2011 a), which definitively established the press in the Province. The nineteenth century also saw the emergence of two major newspapers in Para: A Província do Pará (1876-2002) and the Folha do Norte (1896-1974). These two newspapers will be discussed in more detail in the next section as they were mainly circulated in the twentieth century.

Over the course of the nineteenth century, the press established itself in the Amazon region and adapted to historical and cultural processes in the region. From 1822 (the beginning of $O$ Paraense) to $1908^{3} 730$ newspapers circulated in the state of Para, most of which (722) were in Portuguese and some in Spanish, Italian and French (FIGUEIREDO, 2008, p. 37). Journalism in Para reached another stage of development: the birth of a new century and a new printing press.

\section{THE MAJOR NEWSPAPERS OF PARÁ IN THE 20TH CENTURY}

Founded in the 19th century on March 25, 1876 by Joaquim José de Assis, Francisco de Souza Cerqueira and Antônio Lemos, A Província do Pará (1876-2002) is the longest running periodical in the State and the Amazon. According to Carvalho (2013, p. 50), the first work stoppage occurred in 1900 but six months later, in May 1901, A Província was once again in circulation. On August 29, 1912 its installations burned down and took eight years before it would return to circulation. This occurred on July 
6, 1912 under the direction of Pedro Chermont de Miranda (CARVALHO, 2013, p. 51). On July 27, 1926 publications were once again interrupted due to financial problems, only to resume on February 9, 1947 operated by the Associated Press of Assis Chateaubriand (ROCQUE, 1976, p. 206209). In 1997, the periodical was sold to businessman Gengis Freire and in 2001 was handed over to publicist Miguel Ângelo Arraes (FERREIRA, 2005 , p. 5) who would go on to stop the journal activities in the beginning of March in the following year.

The Folha do Norte (1896-1974) also emerged in the nineteenth century and, in the twentieth century, became one of the most important newspapers. Created on January 1, 1896 by Enéas Martins and Cipriano Santos it is considered the second longest running newspaper in the State. 78 years running (SEIXAS et al, 2013, p. 5) it proposed to "fight for the political-social development in the region by fighting against the politics of Antônio Lemos" (PUBLIC LIBRARY OF PARÁ, 1985, p. 154). It is defined as an independent, newsworthy, political and literary periodical. In 1973 it was sold to journalist and merchant entrepreneur Romulo Maiorana, who was also owner of the $O$ Liberal where he was editor for one more year and then ceased publication (PUBLIC LIBRARY OF PARÁ, 1985, p. 271-273).

On April 9, 1911 Justo Chermont founded yet another big periodical in the history of the Belém press: the Estado do Pará. The newspaper had a political agenda similar to that of the Folha do Norte which was to fight against the politics of former mayor Antônio Lemos of the Republican Party of Para, while supporting Lauro Sodré of the Federal Republican Party (PUBLIC LIBRARY OF PARÁ, 1985, p. 241-242). By opposing state governor Dionísio Bentes, it was destroyed in January of 1928 by civil and military police. Two years later, it covered the 1930 Movement and became an advocate for revolutionists. Afterwards, on December 31, 1962 it stopped circulating due to financial difficulties yet resumed publication on April 20, 1976 and printed in the offset system. The newspaper circulated until December 31, 1980 when it was terminated due to differences in direction and financial difficulties (PUBIC LIBRARY OF PARÁ, 1985, p. 241).

\section{ICONOGRAPHY AND ICONOLOGY}

When Panofsky (a member of the Warburg Institute in Hamburg, Germany) proposed the method of iconography/iconology for interpreting images he was searching to apply his ideas to artworks, his 
area of study. For him (1976, p. 50-52), the interpretation of an image is classified on three levels: "primary or natural subject matter", "secondary or conventional subject matter" and "intrinsic meaning or contents". The "primary or natural subject matter", or pre-iconographic description, is the perception of objects and events in an image and describing them as they are (PANOFSKY, 1976, p. 50). It deals with the "natural" meaning of the image. The "secondary or conventional subject matter", or iconographic analysis, describes the correlations of this image and what they represent (PANOFSKY, 1976, p. 50-51). The "intrinsic meaning or contents" (PANOFSKY, 1976, p.52), or iconological interpretation, is an interpretation of an image and the environment that it belongs to; interpretations are made on more than just its face value.

In his discussions, Kossoy (2001, p. 37) approaches the terms iconography/iconology of photographs, explaining that these three levels of analysis could be classified as description, evocation_of context and analysis/interpretation, respectively. For Kossoy, (2001, p. 37), the three fundamental components to this process are photographs, technique and subject matter: "These are the constitutive elements which have their origin in a process, a cycle which completed when the object's image was crystallized in the bi-dimension of sensible material, in a precise and defined space and time". Kossoy's (2001, p. 101) analysis model is summarized in Table 2:

Table 2 - Iconographic analysis and iconological interpretation.

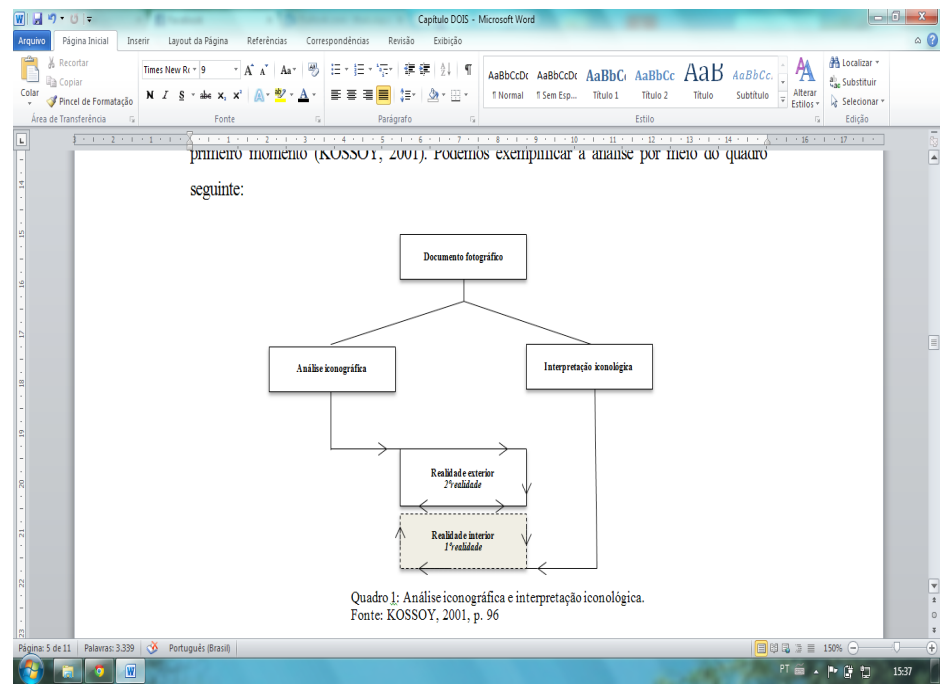

Source: KOSSOY (2001, p. 101). 
Kossoy's methodological model for analyzing images (2001) is wide-ranging, and includes press photography. In this proposal, data on publications of photography should be recovered, focusing on the image and the information around it such as "titles, subtitles and texts in publication" (KOSSOY, 2001, p. 95). A further step is the observation of historical context.

\section{THE ESTADO DO PARÁ NEWSPAPER AND ONE OF THE FIRST PHOTOGRAPHS OF DAILY LIFE IN PARÁ}

A survey by Kossoy (2002, p. 25) to identify the first photographs and establishments active in Brazil between 1833 and 1910 showed that at least 35 photographers or photographic establishments were operating at this time, most of them foreign. These "unknown travellers" would go from place to place offering their work, sharing their knowledge and techniques with other photographers and promoting photographic activity (KOSSOY, 2002, p. 25). This dissemination was important towards introducing photography to the press in Para already present in magazines (1909) and in the newspaper Estado do Pará in 1912 (SEIXAS, 2011 b, p. 301; $2011 d$, p. 12).

In 1912, the Estado do Pará newspaper was one year old and eye-catching. It was $60 \times 42 \mathrm{~cm}$, its pages made up of seven columns separated by lines, the headlines were large and the images were mainly used in advertisements but were also used in materials in the form of illustrations. The newspaper fought against the politics of Antônio Lemos, the former mayor of Belém (PUBLIC LIBRARY OF PARÁ, 1985, p. 241-242). Therefore, this was the theme for many of its illustrations and one of its first journalistic photographs published by the press in Para on September 1, 1912 was of the expulsion of Lemos from the city. It is the first photograph found in the publications available at the time which we consider as journalistic, but that does not mean it was the first published photo since many printing presses which had circulated throughout the nineteenth and twentieth centuries in Para no longer existed, making this claim a little difficult to be verified. 
Figure 1 - One of the first Pará newspaper photographs. Estado do Pará, Sep. 01, 1912, p. 01.

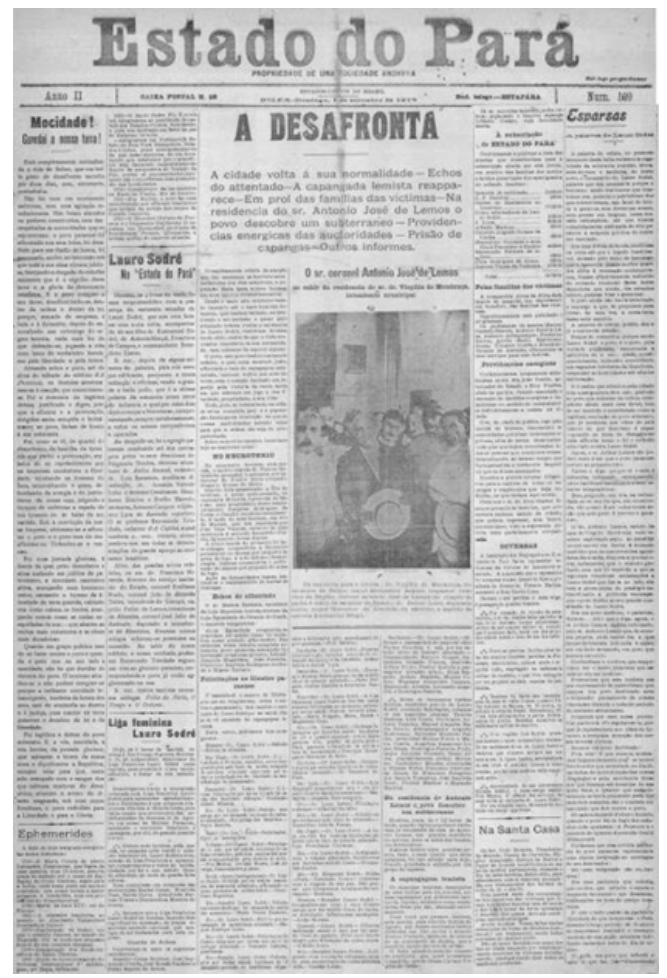

Source: Arthur Vianna Public Library.

Photography was traditionally used to illustrate texts, however, as Kossoy (2007, p. 46) highlights, photographs make up an important source of understanding the past even if it is a fragmented part. They can inform and uninform - or manipulate -, report on certain situations or act as an instrument for the interests of the minority (KOSSOY, 2007, p. 46). He states: "Photographs cannot be thought of as a neutral document, absent of manipulating. There is no innocent document" (KOSSOY, 2007, p. 46). What does the image from Lemos in Figure 1 tell us?

Photographs are published on the front page slightly above center. The main text of the page is connected to the theme of the photograph and the heading "The Revenge" is the front page headline. Photographs are not signed and have specific headlines ("Mr. Colonel Antonio José de Lemos leaving the residence of Dr. Virgilio de Mendonça, mayor of the municipality") and the subtitles name the main authorities around him without giving details of their political connections: 
From left to right: Dr. Virgilio de Mendonça, mayor of Belém; Major Alencastro Araujo, Regional interim inspector; Colonel Antonio José de Lemos (handmade straw hat), former State Senator; Dr. Bruno Lobo, elected representative; Army Major Honorino de Almeida; and Corvette Captain Emmanuel Braga (STATE OF PARÁ, Sep.1, 1912, p. 1).

From the iconography and iconology of Panofsky (1976) and Kossoy (2001), we see that some information is not detailed in images even though the subtitle displays important aspects about the individuals in the photo and can act as a guide to interpreting, as discussed by Barthes (1990, p. 21-34). Important information is related to the political position of the newspaper Estado do Pará which published the image: the press was opposed to Antônio Lemos of the Republican Party of Para and supported his main competition, Lauro Sodré, of the Federal Republican Party (PUBLIC LIBRARY OF PARÁ, 1985, p. 241), who had connections with mayor Mendonça.

At the time it was published, it exposed the critical moment in a political dispute between supporters for Antonio Lemos (called lemistas) and Lauro Sodré (called lauristas) over the upcoming elections for state governor and the influence Lemos had which the party members of Sodré were working to eliminate (ROCQUE, 1996, p. $345,358-359)$. Both were members of two large successful political parties in the golden age of the Amazon rubber boom: ${ }^{4}$ Lemos, who was mayor of the municipality of Belém in successive terms from 1897 to 1911 , a period in which he urbanized and modernized Belém after the European capitals (SARGES, 2000, p. 16, 114-127; 2002, p. 19, 23); and Sodré, who had been the first governor elect of Pará in 1891 after the Proclamation of the Republic and had a successful administration (ROCQUE, 1996, p. 117-125) as well as performing other federal duties.

In June of 1911, older and in poor health, Lemos stepped down as mayor and went to Europe, later to Rio de Janeiro. His political allies asked him to come back to Belem and on February sixth, 1912 (ROCQUE, 1996, p. 312, 349-350) he came back to find the city split between followers of two political parties (SARGES, 2002, p. 72-82). In the words of Rocque $(1996$, p. 357) and Sarges $(2002$, p. 78,198$)$, the city was in chaos. On August 25, 1912 Sodré, seen as the future candidate for state governor, also arrived in Belem and on the night of the $28^{\text {th }}$ fell victim to an attack allegedly carried out by Antonio Lemos supporters (ROCQUE, 1996, p. 369-380; SARGES, 2002, p. 79). This intensified the animosity between the camps as each one of the three newspapers that make up the corpus of this study had put the blame on the other political 
opponent. In retaliation, Rocque (1976, p. 120-125; 1996, p. 380-399) writes that the head office of A Província do Pará and Lemos's house were both set on fire. Lemos himself was dragged through the streets in his pyjamas to Mayor Virgílio de Mendonça's house where he resigned from office. Lemos was forced to leave the city and went on to Rio de Janeiro where he passed away on October 2, 1913 (ROCQUE, 1976, p. 128; 1996, p. 400-402; SARGES, 2002, p.80). ${ }^{5}$

Leal (1998, p. 25) emphasizes that the downfall of Lemos in 1912 gave rise to the value of photojournalism: "After Lemos's downfall - after being dragged through the streets, stoned by the public, his property destroyed, his house burned-, the photographers started to pay more attention to the facts in the city".

Only one more photograph appeared in the Estado do Pará on the fifth of September, 1912. It was about victims of the fire at the $A$ Província do Pará head office and the title was "For the victims of the duty", which shows the emphasis given to that event in that month. In October 1912 the Estado do Pará only published illustrations of Portuguese authorities and a bust of Lauro Sodré.

In a previous study (SEIXAS, 2011b, p. 301-302), we noted that photography was used more frequently in periodicals only as of 1919. We will now present some characteristics of photojournalism in 1920s Para.

\section{PHOTOJOURNALISM IN THE 1920S}

Up until 1920 illustrations (drawings) of busts were still common but once photographers started taking pictures of the busts of politicians, the illustrations were left to the side and photography took over. Sports images started to appear in 1920, most of which were related to football. New angles and framing was experimented with. From this point forward, photographs of foreign issues gained space in local press.

At the Folha do Norte emerged photograph columns - Galeria Infantil and Galeria Feminina - published on the first page. In another study (SEIXAS, 2011 c, p. 11) we observed the importance photographs gave to these infantile and feminine columns which had only subtitles to identify the portraits: "For a time when using images in daily newspapers was still rare, the presence of this highlighted resource gave the page added value".

The use of photography as a social form of complaining was 
found on the front page of the April 26th edition of the Estado do Pará in 1920, one of the first of these kinds seen in the study (Figure 2). It shows an image depicting the state of the homeless in Belém. The text writes: "Our photograph of the day belongs to the dozens of outcasts who swarm the city [...]" (STATE OF PARÁ, Apr. 26, 1920 p. 1). On the 30th of the same month, another photograph (Figure 3) shows the state of the housing for the "miserable" (ESTADO DO PARÁ, Apr. 30 1920, p. 1).

Once published, these images of the city and its "outcasts" (ESTADO DO PARÁ, Apr. 26 1920, p. 1) became a "second generation image-object" (KOSSOY, 2001, p. 42). In other words, they represent an unchangeable, fixed reality as Kossoy states, which can be interpreted in various ways, for example as a complaint about the indifference on the part of the government in relation to these individuals and the city itself, or even as a place where these invisible, "miserable" people who have been pushed to the outside of society can be seen" (ESTADO DO PARÁ, Apr. 30 1920, p. 1).

Figure 2 - Photograph of a homeless man.

Estado do Pará, Apr. 26, 1920, p. 1

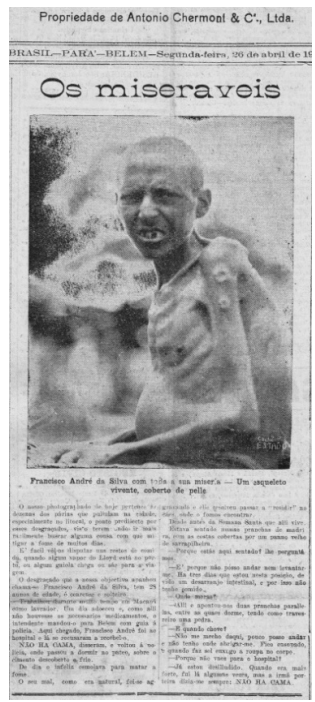

Source: Arthur Vianna Public Library.
Figure 3 - The Santo Antônio Square in Belém.

Estado do Pará, Apr. 30, 1920, p. 1

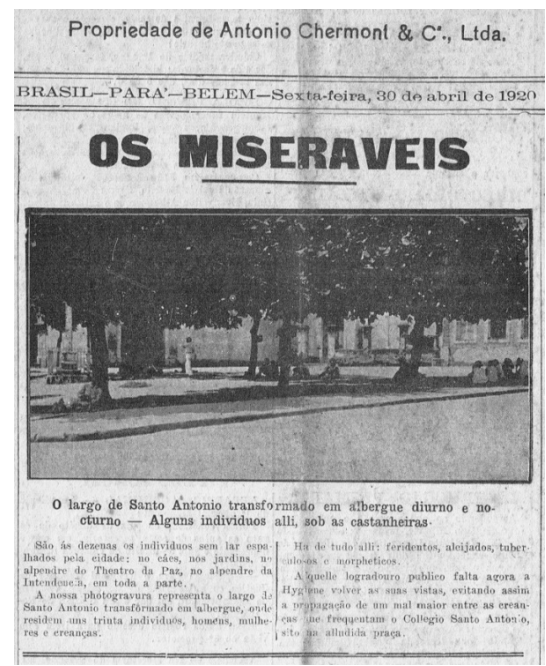

Source: Arthur Vianna Public Library. 
One of the first images of the Círio de Nazaré - a Catholic procession which has been held in Belém since 1793 and currently attracts around two million people on the second Sunday of October (INSTITUTO DO PATRIMÔNIO HISTÓRICO E ARTÍSTICO NACIONAL, 2006, p. 29-30) - was published in the Folha do Norte on October 10,1920 . The picture is of the Virgin of Nazareth decorated with ornaments and used to lead the procession of 1920 (Figure 4). This could have been one of the first photojournalistic coverages of the procession in a local daily newspaper. The data shows that the press did cover various issues pertaining to the city whether on the homeless or a staged religious event like the Círio de Nazaré.

The use of photography to advertise an event that occurred more than a hundred years ago shows how much newspapers valued the procession in their coverage. This is verified due to the number of photographs that were used every October from that year onward. The photographs in the next day's newspaper showed the crowds that showed up (Figure 5).

Figure 4 - Image of the Virgin of Nazareth. Folha do Norte, Oct. 10, 1920, p. 1

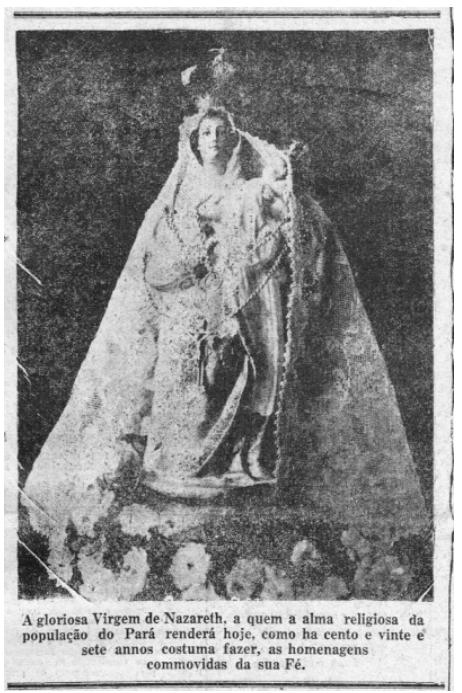

Source: Arthur Vianna Public Library.
Figure 5 - Photo coverage of the Círio de Nazaré. Folha do Norte, Oct. 11, 1920, p. 1

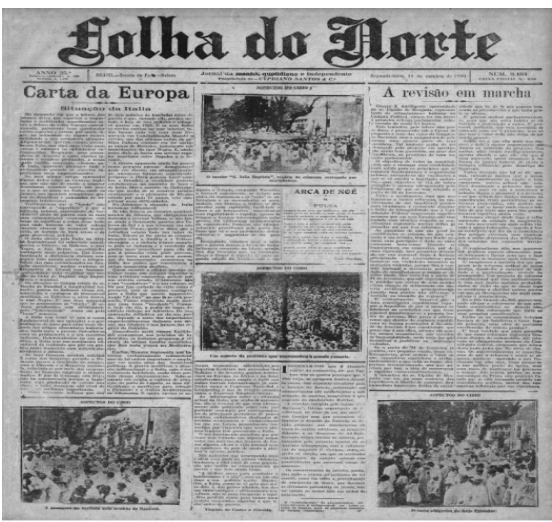

Source: Arthur Vianna Public Library.

On July 6, 1920 A Província do Pará resumed publication stating it 
was in "the beginning of a new era" (A PROVÍNCIA DO PARÁ, July 7, 1920, p.1). The newspaper was looking to restructure itself however it still did not use many photographs in the first year. Just like the Folha, A Província also published pictures of the Sunday Círio de Nazaré procession, as well as a picture of the Saint which looks more like an illustration, and the photograph of the Basilica de Nazaré; the finish line for the parade. The newspaper didn't used to circulate on Mondays, so on Tuesday October 12 it published two pictures of the parade at the finish line in the same style as the Folha do Norte.

The cleanliness of the city (Figure 6) and social issues about the capital of Para were a few worrisome issues for A Província in the 1920s. These preoccupations materialized in pictures showing holes in the streets, garbage and the state of the sewage system (A PROVÍNCIA DO PARÁ, Oct. 15 1920, p. 1; Oct. 22 1920, p. 1).

Figure 6 - One of the streets of Belém in the 1920s.

Província do Pará, Oct. 15, 1920, p. 1

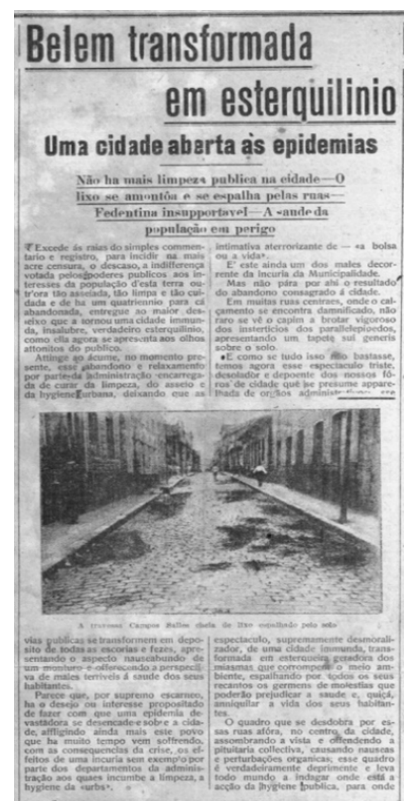

Source: Arthur Vianna Public Library.

These images, just like the documents, preserve the signature of Belém as it was at the beginning of the 20th century; time is a characteristic of photography, according to Kossoy (2007, p. 142). He believes that time is reality in photographs, it is ephemeral; and that reality is represented in pictures, it is eternal. 


\section{PHOTOJOURNALISM IN THE BELÉM PRESS FROM 1930 TO 1950}

Out of the big newspapers in circulation in Belém between 1930 and 1940 only the Folha do Norte was available for study (Cf. Table 1). Founded on January 1, 1896, it printed pictures in honor of its anniversary in 1930. Page 3 of the first year's edition was called "Golden Page" and was almost completely image-based. These were the first photographs found with credits attached to them according to the clippings particular to this study January, April, July and October every ten years from 1900 to 1950). The pictures were signed as Oswaldo Gry in 1930 - some only as Oswaldo - and it appears to have been a handwritten signature on the photographs.

The pictures portrayed parks, plazas and historic buildings in Belém, acting as a photo album of the city. There are other pictures of leaders and other open spaces like harbors, bridges, plantations and highways. The original format of these pictures offer glimpses of the time in which they were taken. Kossoy (2001, p. 40) calls them "imagepicture", "first source" (KOSSOY, 2001, p. 42) or "first reality" as these terms describe a "fixed, unchangeable and irreversible" image (KOSSOY, 2009, p. 47). Impressions or other reproductions of this image (for example, in the press) have characteristics different from the original, making it a "second generation image-object" or a "secondary source" (KOSSOY, 2001, p. 42), also a "fixed, unchangeable second reality" but likely to "multiple interpretations" (KOSSOY, 2009, p. 47) evident in the newspaper's interest in covering the transformations in the city and its surrounding area.

At the Folha do Norte there is a photo report on the "future president of Brazil's visit to the United States" the photos of which are credited to Arthur Coelho who appears to be referred to as an international correspondent who did not work exclusively for the Folha but contributed to journalism in Para. The caption reads:

We thank Arthur Coelho, correspondent for the 'Amazonia Brasileira' in the U.S, for these photographs, the first to be published in newspapers in northern Brazil, which he sent to us from New York, courtesy of the Folha (FOLHA DO NORTE, July 23, 1930, p. 1).

On January 1, 1940 the traditional edition of the Folha had photographs not only of Belém but from various other municipalities in the State. The newspaper also had an evening edition which published photographs just as the morning edition did. The World of Sports section was dominated with photographs of football players posing; there were very few pictures of the game being played on the field. 
In this same year the newspaper published photos of the Second World War, all were distributed by agencies like the Associated Press (AP) (Figures 7 and 8).

Figure 7 - Soldier killed in combat. Folha Vespertina, Jan. 22, 1940, p. 1

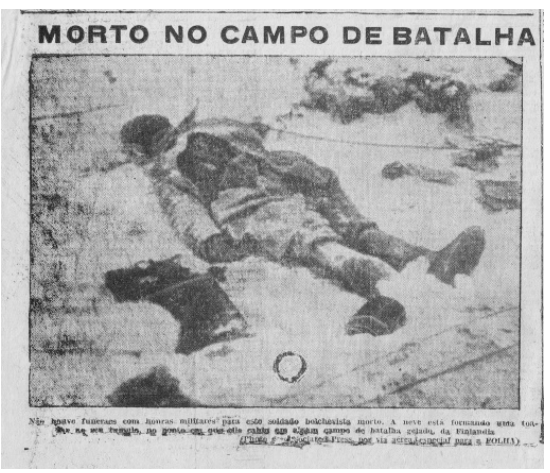

Source: Arthur Vianna Public Library.
Figure 8 - Images of the war. Folha Vespertina, Jan. 24, 1940, p. 1

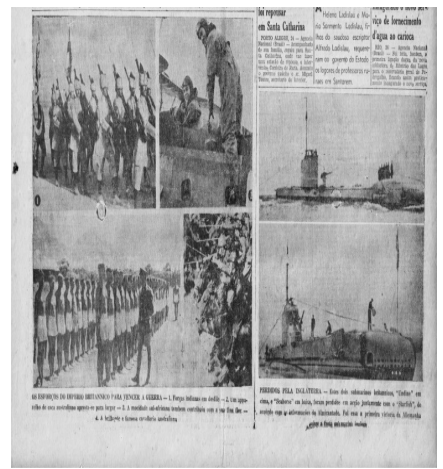

Source: Arthur Vianna Public Library.

Even with the conflict going on in Europe, there were more photographs of local events being published in the periodical. The issues that garnered the most attention were on politics (Figures 9 and 10 ), sports, the state of health on the street and political meetings.

Figure 9 - Photograph of police affairs. Folha Vespertina, Jan. 06, 1940, p. 4

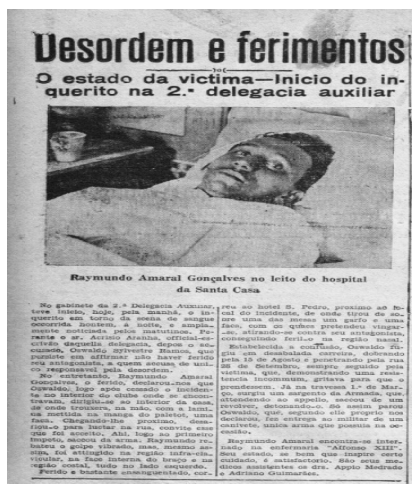

Source: Arthur Vianna Public Library.
Figure 10 - The nut theft case. Folha Vespertina, Apr. 13,1940 , p. 4

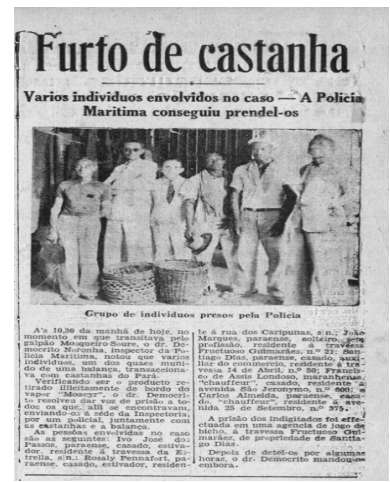

Source: Arthur Vianna Public Library. 
In 1950, the Brazilian newspapers went through an adaptation process based on the North American model (RIBEIRO, 2006, p. 427). The modernization of printing presses in the country was not a homogenous one, but a few page layout differences were already visible in the Belém press.

The number of photographs on international issues began to outweigh those on local issues at Folha do Norte as radio and telephoto systems made submitting information easier. National and international photos were sent by the Associated Press (AP) and the Agência Jornal of Brazil. In 1950, local photographs were only included on the front page of the Folha if they were depicting political meetings and assemblies.

Contrary to Folha, A Província placed much more value on photographs for local issues such as accidents. The international photos were sent by the International News Photos (INP) and the Meridional. Words like "blatant" and "collected moment" were common in captions, integrating a discourse which recognized photojournalism as capturing instant fragments of reality (KOSSOY, 2009, p. 129).

On January 8, 1950 the newspaper published a text and photograph from historian Ernesto Cruz (Figure 11) and credited him. The data observed in this study showed that photographers from this period onward were credited for their work in special reports, but not so for other types of material.

Figure 11 - The Our Lady of Mercy Church in Belém-PA.

A Província do Pará, Jan. 08, 1950, p. 9

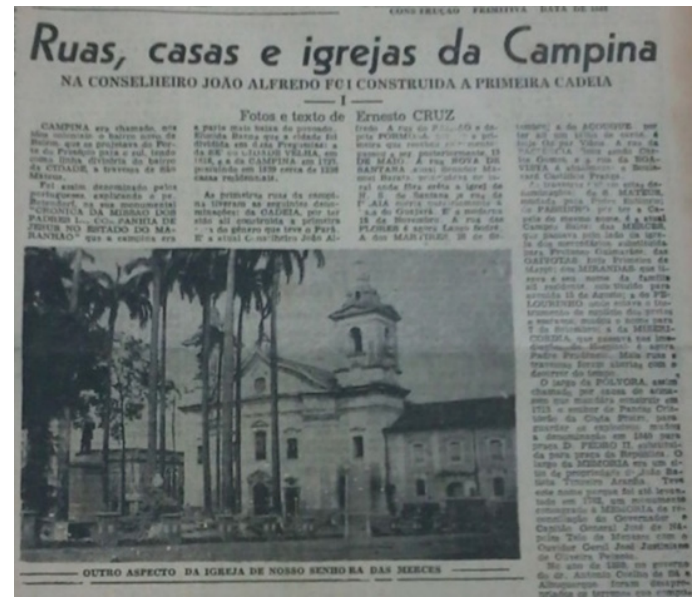

Source: Arthur Vianna Public Library. 
This study presented characteristics of photojournalism in the printed press of Belém during the analyzed period. Photojournalism acquired other nuances in the following decades but this is a story which has yet to be told.

\section{FINAL CONSIDERATIONS}

At the beginning of the twentieth century, the first photographs used in newspapers showed that the periodicals were recognizing the power of images. This was apparent in newspaper reports, mainly on politics, which would go through a few changes over the following decades, putting more value on pictures that portrayed the social tragedies and problems in the city, the police and sports, but also the architectural beauty of Belém and other municipalities of Pará. The images of these events were guiding the editorial lines at the newspapers, just behind newsworthy criteria for published texts.

The newspapers changed their configuration over the four decades researched in this study; they reorganized texts and titles and added photographs to their reporting. After newspapers restructured their layouts in 1950, pictures became more of a focal point and have been covering more and more of the pages. They also show more direct dialogues in texts than the previous decades (the titles used to only describe the subjects in the pictures).

Trying to condense half a century of history into just one study is a huge challenge, but the purpose of this study was not to wear the topic thin, this would be an impossible task due to the wealth of information available. It is this wealth that urges us to continue the search to understand a little more of the course of photojournalism in a huge and complex region such as the Amazon.

*This paper was translated by Lee Sharp.

\section{BIBLIOGRAPHY}

BARTHES, Roland. A retórica da imagem. In: O óbvio e o obtuso. 2. ed. Rio de Janeiro: Nova Fronteira, 1990, p. 27-43. 
BIBLIOTECA PÚBLICA DO PARÁ. Jornais Paraoaras: catálogo. Belém: Secretaria de Estado de Cultura, Desportos e Turismo, 1985.

CARVALHO, Vanessa Brasil de Carvalho. A ciência na imprensa paraense em 130 anos: um estudo de três grandes jornais diários. 2013. Dissertação (Mestrado em Ciências da Comunicação) - Programa de Pós-Graduação Comunicação, Cultura e Amazônia, Universidade Federal do Pará, Belém, 2013.

COELHO, Geraldo Mártires. O surgimento da imprensa no Pará. Revista Pará Zero Zero: imprensa, ideias e poder, Belém, Ano II, n. 5, p. 22 - 39, Aug/Sep., 2008.

FERREIRA, Paulo Roberto. Mais de 180 anos de imprensa na Amazônia. In: ENCONTRO NACIONAL DE HISTÓRIA DA MÍDIA (ALCAR), 3., 2005, Novo Hamburgo, RS. Anais... São Paulo: ALCAR, 2005, p. 1-11. Available at: $<$ http://www.ufrgs.br/alcar/encontros-nacionais-1/encontros-nacionais/3o-encontro-2005-1?b_start:int=100>. Accessed on: Sep. 23, 2014.

FICUEIREDO, Aldrin Moura de. Uma história impressa: os jornais paraenses, 1822-1922 (primeira parte). ZYG360.com. Ano I, n 4 , p. 3638 , nov. 2008 .

INSTITUTO DO PATRIMÔNIO HISTÓRICO E ARTÍSTICO NACIONAL. Círio de Nazaré. Dossiê I. Rio de Janeiro: IPHAN, 2006.

KOSSOY, Boris. Fotografia e história. 5. ed. São Paulo: Ateliê Editorial, 2001.

Dicionário histórico-fotográfico brasileiro: fotógrafos e ofício da fotografia no Brasil (1833-1910). São Paulo: Instituto Moreira Salles, 2002. Os tempos da fotografia: o efêmero e o perpétuo. 2. ed. Cotia, SP: Ateliê Editorial, 2007.

Realidades e ficções na trama fotográfica. 4. ed. São Paulo: Ateliê Editorial, 2009.

LEAL, Cláudio de La Rocque. Retrato paraense. Fundação Romulo Maiorana, Belém, 1998.

PANOFSKY, Erwin. Iconografia e iconologia uma introdução ao estudo da arte da renascença. In: Significado nas artes visuais. São Paulo: Perspectiva, 1976, p.47-87.

RIBEIRO, Ana Paulo Goulart. Modernização e concentração: a imprensa carioca nos anos 1950-1970. In: NEVES, Lúcia Maria Bastos P.; MOREL, Marcos; FERREIRA, Tania Maria Bessone da C. (Org.). História e imprensa: representações culturais e práticas de poder. Rio de Janeiro: DP\&A, FAPERJ, 2006. p. 426-435.

ROCQUE, Carlos. A história de A Província do Pará. Belém: Mitograph, 1976. 
Antonio Lemos e sua época: história política do Pará. Belém: CEJUP, 1996.

SARGES, Maria de Nazaré. Memórias do "Velho Intendente" Antônio Lemos (1869-1973). Belém: Paka-Tatu, 2002.

Belém: riquezas produzindo a Belle-Époque (1870-1912). Belém: Paka-Tatu, 2000.

SEIXAS, Netília Silva dos Anjos. Panorama da imprensa em Belém: os jornais de 1822 a 1860. In: AMARAL FILHO, Otacílio et al (Org.). Comunicação midiatizada na e da Amazônia. Belém: FADESP, 201 1a, p. 225-248.

- O uso da imagem na mídia impressa de Belém: percurso e configuração. In: PEREIRA, Ariane et al (Org.). Fatos do passado na mídia do presente: rastros históricos e restos memoráveis. São Paulo: Intercom e-livros; UNICENTRO, abril de 2011 b, p. 279-306. Available at: <http://www.portcom.intercom.org.br/ebooks/arquivos/8f069e78e6bb 470cblad9ca1718a6cb7.pdf>. Accessed on: Feb. 26, 2015.

Os primeiros passos do colunismo social no Pará: Folha do Norte e A Província do Pará. In: ENCONTRO NACIONAL DE HISTÓRIA DA MÍDIA, 8., 2011 , Guarapuava, PR. Anais... São Paulo: ALCAR, 2011c, p. 1-13. Available at: <http://www.ufrgs.br/alcar/encontros-nacionais-1/encontrosnacionais/8o-encontro-2011-1/artigos/Os\%20primeiros\%20passos $\% 20$ do\%20colunismo\%20social\%20no\%20Para\%20Folha\%20do\%20Norte\%20 e\%20A\%20Provincia\%20do\%20Para.pdf/view>. Accessed on: Oct.7, 2014.

Polícia, justiça e mídia impressa no Pará: tecendo sentidos. In: CONGRESSO INTERNACIONAL DA ASSOCIAÇÃO LATINOAMERICANA DE ESTUDOS DO DISCURSO, 2011, Belo Horizonte, MG. Resumo... Belo Horizonte: UFMG, $2011 \mathrm{~d}$.

A trajetória da imprensa no Pará. Projeto de pesquisa, Edital Universal MCTI/CNPq N 14/2012. Em andamento. Belém: UFPA, 2012.

et al. Jornal Folha do Norte e suas publicações sobre a Amazônia, o Pará e a cidade de Belém. In: ENCONTRO NACIONAL DE HISTÓRIA DA MÍDIA (ALCAR), 9., 2013, Ouro Preto, MC. Anais... São Paulo: ALCAR, 2013, p. 1-11. Available at: <http://www.ufrgs.br/alcar/encontrosnacionais-1/9o-encontro-2013/artigos/gt-historia-da-midia-impressa/ jornal-folha-do-norte-e-suas-publicacoes-sobre-a-amazonia-o-para-e-acidade-de-belem>. Accessed on: Sep. 23, 2014.

SOUSA, Jorge Pedro. Fotojornalismo: uma introdução à história, às técnicas e à linguagem da fotografia na imprensa. 1. ed. Porto, 2002. Available at: <http://www.bocc.ubi.pt/pag/sousa-jorge-pedrofotojornalismo.pdf>. Accessed on: Sep. 23, 2014. 
NOTAS

1 Study conducted on research project "The trajectory of the press in Pará", sponsored by the National Counsel of Scientific and Technological Development, MCTI Universal Public Notice/CNPq No 14/2012.

2 We use the term image in a general sense, referring to both photography and other types of illustrations except where the term photography was specifically necessary to be used.

3 As well as Alfredo de Carvalho who, in 1908, published a survey on the development of the press in Brazil, and Remígio de Bellido who, in the same year in Para, edited the Newspaper Catalogues of Para with information about the state periodicals.

4 According to Sarges $(2000$, p. 48,89$)$, this was for the period between 1870 and 1912 .

5 On the same day (Dec.17, 1973) that A Província do Pará inaugurated its new printing system, the ashes of Antonio Lemos returned to Belem from Rio de Janeiro on request of the then mayor, Nélio Lobato. The remains of the former mayor were taken to the Palace of the Mayor (ROCQUE, 1976, p. 230-231).

Netília Silva dos Anjos Seixas is a professor at the Faculdade de Comunicação and Programa de Pós-Graduação Comunicação, Cultura e Amazônia at the Universidade Federal do Pará, Brazil. Doctor in Linguistics at the Universidade Federal de Pernambuco, Brazil.

Thaís Christina Coelho Siqueira is a CNPq DTI-C scolarship fellow of the project "GLOBAL ITV: Interoperability of Interactive and Hybrid TV systems - A new advanced scheme for future services and applications in a global environment", PIBIC-CNPq former fellow and currently collaborator in the research project "A trajetória da imprensa no Pará". Degree in Social Communication - Journalism at the Universidade Federal do Pará, Brazil. E-mail: thaissiqueira.jor@gmail.com

RECEIVED ON: 27/02/2015 | APPROVED ON: 26/08/2015 